\title{
Aplikasi Pupuk Bokashi Padat Berbahan Dasar Feses Ayam dengan Level Berbeda terhadap Pertumbuhan dan Produksi Lamtoro (Leucaena leucocephala)
}

Stefanus Tnines ${ }^{\mathrm{a}}$, dan Oktovianus Rafael Nahak ${ }^{\mathrm{b}}$

a Fakultas Pertanian, Universitas Timor, Kefamenanu, TTU - NTT, Indonesia, email: stefanustnines699@gmail.com

b Fakultas Pertanian, Universitas Timor, Kefamenanu, TTU - NTT, Indonesia, email: oktovianusrafael@yahoo.co.id

\section{Article Info}

Article history:

Received 13 Oktober 2017

Received in revised form 17 November 2017 Accepted 2 Desember 2017

DOI:

https://doi.org/10.32938/ja.v3i1.420

Keywords:

Bokashi Padat, Produksi Lamtoro

\section{Abstrak}

Penelitian ini dilaksanakan pada kebun percobaan Fakultas Pertanian, Universitas Timor, Kelurahan Sasi, Kecamatan Kota Kefamenanu, Kabupaten TTU pada bulan Juli sampai September 2017. Tujuan dari penelitian ini untuk mengetahui pengaruh aplikasi pupuk bokashi padat berbahan dasar feses ayam dengan level berbeda terhadap pertumbuhan dan produksi tanaman lamtoro. Perlakuan yang diuji dalam penelitian ini terdiri dari $\mathrm{R}_{0}=$ Tanpa bokashi., $\mathrm{R}_{1}=$ Aplikasi pupuk bokashi $250 \mathrm{~g} / \mathrm{lubang}$ tanam., $\mathrm{R}_{2}=$ Aplikasi pupuk bokashi $500 \mathrm{~g} / \mathrm{lubang}$ tanam., $\mathrm{R}_{3}=$ Aplikasi pupuk bokashi $750 \mathrm{~g} /$ lubang tanam yang diamati efeknya terhadap Tinggi tanaman, jumlah helai daun, berat segar daun, berat kering daun, berat segar akar, berat kering akar. Hasil penelitian ini menunjukkan bahwa pemberian bokashi padat pada level $250 \mathrm{~g} /$ lubang tanam secara signifikan mempengaruhi pertumbuhan dan produksi lamtoro yaitu sebesar $43,51 \mathrm{~cm} / \mathrm{tanaman}$, jumlah helai daun 59,18 helai/tanaman, berat segar daun 21,79 g/tanaman, berat kering daun 8,45 g/tanaman, berat segar akar 13,20 g/tanaman, berat kering akar 5,74 g/tanaman.

\section{Pendahuluan}

Tanaman lamtoro merupakan pakan ternak yang potensial dan telah dikembangkan oleh masyarakat peternak di Kabupaten Timor Tengah Utara karena memiliki kualitas nutrisi dan kemampuan adaptasi yang tinggi pada lahan kering. Tanaman lamtoro (Leucaena leucocephala) termasuk salah satu jenis leguminosa yang telah banyak dimanfaatkan sebagai pakan ternak. Komposis daun lamtoro menurut Pamungkas $d k k$., (2011) adalah bahan kering 27,68\% bahan organik 91,98\%; protein kasar 23,16\%; lemak kasar 4,35\%; dan serat kasa 21,22\%. Sedangkan Abou-Elezz et.al., (2011) melaporkan bahwa lamtoro mengandung bahan kering $91 \%$; protein kasar 23,61\%; Abu 8,27\%; kalsium $(\mathrm{Ca})$ $1,62 \%$; fosfor (P) $0,18 \%$; ADF $23,69 \%$; NDF 40,38\% dan energi bruto (GE= Gross Energy) $19,17 \mathrm{MJ} / \mathrm{kg}$. Selain itu daun lamtoro juga mengandung Ca 2,36\%, P 0,23\% dan $\beta$-carotene $536 \mathrm{mg} / \mathrm{kg}$ (Devi $d k k ., 2013$ ).

Peningkatan nilai kesuburan tanah pada lahan kering dapat ditempuh dengan penerapan aspek teknologi melalui kegiatan pemupukan dengan tujuan menyediakan unsur hara bagi tanaman. Pada tahap pertumbuhan dan perkembangannya, tanaman lamtoro membutuhkan unsur hara. Unsur hara dapa diasup dari beberapa jenis pupuk organik seperti Bokashi. Bokashi merupakan pupuk organik yang kaya akan hara seperti N, P, K, C, KCL. Selain sebaga bahan makanan bagi tanaman unsur hara juga berperan dalam membentuk kondisi yang ideal pada tanah sehingga mikroorganisme tanah dapat tumbuh dan berkembang. Adapun kandungan Bokashi terdiri dari: N: 1,25\%, P: 1,02\%, K 1,44\%, KCL: 7,60\%, H20: 8,50\%, C: 26,90\% (Sunardi, 2009). Pembuatan pupuk Bokashi tergolong sederhana dan tidak membutuhkan biaya yang mahal, namun teknologi ini belum dikenal oleh banyak kalangan peternak mengingat akses informasi yang masih terbatas pada masyarakat peternak.

Menurut Plantamor, (2012) klasifikasi dari tanaman lamtoro adalah sebagai berikut:

$\begin{array}{llll}\text { Kingdom } & \text { : Plantae } & \text { Devisio } & : \text { Magnoliophyta } \\ \text { Kelas } & \text { : Magnoliopsida } & \text { Ordo } & : \text { Fabales } \\ \text { Familia } & \text { : Fabaceae } & \text { Genus } & : \text { Leucaena }\end{array}$

Species : Leucaena leucocephala.

Lamtoro merupakan tanaman perdu pohon yang pertumbuhannya mampu mencapai tinggi 5-15 m, bercabang banyak dan kuat, dengan kulit batang abu abu dan lenticel yang jelas. Tanaman ini tumbuh tegak dengan sudut pangka antara batang dengan cabang $45^{\circ}$. Daunnya kecil, tulang daun menyirip ganda dua (bipeianantus) dengan 4-9 pasangan sirip yang berjumlah sampai 408 pasang, tiap sirip tangkai daun mempunyai 11-22 helai anak daun. Bunganya merupakan bunga bongkol atau membulat (Eappitullum). Batangnya berwarna putih kecokelatan atau cokelat kemerah-merahan. Buah tipis dan datar, berwarna kecokelatan ketika masak. Tumbuh secara liar maupun ditanam pada ketinggian $1200 \mathrm{~m}$ (Purwanto, 2007). Lamtoro menyukai iklim tropis yang hangat (suhu harian $25-30^{\circ} \mathrm{C}$ ), ketinggian di atas $1000 \mathrm{~m}$ dpl dapat menghambat pertumbuhan. Tanaman ini tumbuh baik di wilayah dengan kisaran curah hujan 650-3.000 mm per tahun.

Lamtoro (Leucaena leucocephala) merupakan tanaman leguminosa pohon serba guna, berasal dari Amerika tengah dan Meksiko. Lamtoro umumnya ditanam sebagai pakan ternak, tanaman pagar dan tanaman pelindung untuk kopi dan vanili. Sebagian masyarakat memanfaatkan buah dan daun muda untuk sayur. Daunnya dipergunakan sebagai pakan ternak dan batangnya dimanfaatkan sebagai perabotan dan kayu bakar. Di Indonesia produksi lamtoro dapa mencapai 200.000 metrik ton per tahun. Di kawasan Asia Tenggara lamtoro dapat di jumpai di daerah yang mempunyai ketinggian1-1500 $\mathrm{m}$ di atas permukaan laut (Putri \& Rahmawati, 2012).

Jenis tanaman untuk pakan ternak dipilih lamtoro (Leucaena leucocephala), karena tanaman ini mempunyai manfaat bagi masyarakat dan juga mampu memperbaiki sifat tanah. Lamtoro dapat mencapai tinggi 10-20 m, dengan percabangan yang rendah dan banyak. Lamtoro banyak digunakan sebagai tanaman penghijauan atau pencegahan erosi karena perakarannya yang dalam. Daun-daun dan ranting mudah lamtoro dapat digunakan sebagai pakan ternak karena kandungan proteinnya yang tinggi. Lamtoro dapat menghasilkan
70 ton hijauan segar atau 20 ton bahan kering/ha/tahun. Komposisi kimia yang terdapat pada lamtoro dalam bahan kering terdiri atas $25,90 \%$ protein kasar, $20,40 \%$ serat kasar dan $11 \%$ abu $(2,30 \%$ Ca dan $0,23 \% \mathrm{P})$, karotin $530,00 \mathrm{mg} / \mathrm{kg}$ dan tanin 10,15 mg/kg (Haris, 2012). Daun lamtoro mempunyai tingka kecernaan dalam rumen cukup tinggi, yaitu sekitar $69 \%$ (Suhartati, 2012). Tingkat ketercernaan ini pada ruminansia, tertinggi di antara jenis polongpolongan dan hijauan pakan ternak tropis lainnya. Lamtoro yang ditanam cukup rapat dan dipelihara dengan baik dapat menghasilkan banyak hijauan pakan ternak. Daunnya mudah terdekomposisi sehingga sering digunakan sebagai mulsa dan pupuk hijau.

Buah lamtoro yang masih muda dapat digunakan sebagai sayur atau lalap mentah. Kayu lamtoro mempunyai nilai kalori yang cukup tinggi, yaitu sebesar $4,197 \mathrm{kkal} / \mathrm{kg}$ dengan kadar abu 5,78\% (Cahyono $d k k ., 2008$ ). Selanjutnya dikatakan lamtoro banyak ditanam sebagai tanaman sela untuk mengendalikan erosi dan meningkatkan kesuburan tanah. Lamtoro memiliki perakaran yang dalam serta perakarannya terdapat nodul-nodul akar yang mampu mengikat nitrogen sehingga tidak mudah tumbang oleh angin yang kencang.

Pertumbuhan adalah pertambahan massa, ukuran, volume yang bersifat irreversible (tidak dapat balik). Pertumbuhan tanaman ditunjukkan oleh adanya pertambahan ukuran dan bahan kering yang mencerminkan dari pertambahan protoplasma. Pertumbuhan tanaman melalui tiga proses penting yaitu: Pembelahan sel, Perpanjangan sel, dan Diferensiasi sel. Ketiga proses ini akan mengembangkan batang, daun dan sistem perakaran tanaman (Handayani, 2002).

Potensi produksi pakan dari tanaman Lamtoro saat ini berpotensi dapa ditingkatkan. Lamtoro yang berumur 13,5 bulan mampu menghasilkan hijauan segar sebanyak 1.433 gram/pohon atau 431 gram BK. Dari Berat segar tersebut dihasilkan BK berturut-turut 69,2 gram, 51,8 gram, dan 63,0 gram; atau berturutturut sebanyak 8,27 ton, 1,48 ton, 1,42 dan 1,53 ton hijauan segar atau 2,88 ton, 0,46 ton, 0,36 ton, dan 0,42 ton bahan kering pada populasi tanaman 6667 tanaman/ha. Untuk lamtoro berumur 26,5 bulan mampu menghasilkan hijauan dalam bentuk BK sebanyak 0,551 kg per pohon (Purwantari, 2005).

Lamtoro merupakan leguminosa pohon dengan kandungan protein yang tinggi, yaitu $15 \%$ sampai 38\% (Zayed $d k k ., 2014$ ). Balai Pengkajian Teknologi Pertanian Nusa Tenggara Timur merekomendasikan tanaman lamtoro kultivar Tarramba sebagai leguminosa berproduktivitas tinggi, tahan kekeringan, dan tahan hama kutu loncat untuk dijadikan salah satu alternatif pakan suplemen karena tingginya kandungan protein, vitamin, dan mineral. Hasil analisis menunjukkan, penanaman legum pohon (gamal dan lamtoro) pada lahan pinggir pembatas tegalan dan perkebunan sebagai sumber pakan berpotens meningkatkan kandungan unsur nitrogen di dalam tanah dalam jangka panjang, yaitu dari 83,3 ton menjadi 91,6 ton. Nitrogen adalah unsur hara makro esensial untuk produksi tanaman di Indonesia karena tanah di Indonesia umumnya mengandung sedikit nitrogen (Hindersah \& Simarmata, 2004).

Lamtoro dapat menghasilkan 70 ton hijauan segar atau 20 ton bahan kering/ha/tahun. Komposisi kimia yang terdapat pada lamtoro dalam bahan kering terdiri atas $25,90 \%$ protein kasar, $20,40 \%$ serat kasar dan $11 \%$ abu $(2,30 \%$ Ca dan 0,23\% P), karotin 530,00 mg/kg dan tanin 10,15 mg/kg (Haris, 2012) Daun lamtoro mempunyai tingkat kecernaan dalam rumen cukup tinggi, yaitu sekitar 69\% (Suhartati, 2012)

\section{Metode}

Penelitian ini dilaksanakan pada kebun percobaan Fakultas Pertanian, Universitas Timor, Kelurahan Sasi, Kecamatan Kota Kefamenanu, Kabupaten TTU selama 3 bulan dimulai dari bulan Juli sampai September 2017. Adapun peralatan yang digunakan dalam penelitian ini terdiri dari: peralatan ukur seperti mistar, meteran; peralatan laboratorium seperti timbangan dan oven; peralatan bercocok tanam seperti parang, linggis, sekop, pacul, ember, meter roll, karung, termometer. Bahan yang digunakan dalam penelitian ini yakni bibit atau anakan lamtoro sebanyak 240 anakan. Bedeng sebanyak 16 petak dengan ukuran $250 \mathrm{x}$ $150 \mathrm{~cm}$, feses ayam $50 \mathrm{~kg}$, daun gamal $20 \mathrm{~kg}, 10 \mathrm{~kg}$ dedak padi, EM4 + gula air $1000 \mathrm{ml}$, terpal, parang, wadah dan air bersih. 
Penelitian ini menggunakan Rancangan Acak Kelompok (RAK) dengan 4 perlakuan dan 4 ulangan sehingga yang terdiri dari : $\mathrm{R} 0=$ Tanpa pemberian pupuk Bokashi (kontrol), R1= Bokashi 250 gram/lubang tanam, R2= Bokashi 500 gram/lubang tanam dan R3= Bokashi 750 gram/lubang tanam. Kandungan hara tersedia dalam Bokashi dapat dilihat pada Tabel 1.

Tabel 1. Ketersediaan Hara Berdasarkan Dosis Bokashi

\begin{tabular}{cccc}
\hline \multirow{2}{*}{ Dosis Pupuk $(\mathrm{g})$} & \multicolumn{3}{c}{ Kandungan Hara Tersedia } \\
\cline { 2 - 4 } & $\mathrm{N}$ & $\mathrm{P}$ & $\mathrm{K}$ \\
\hline 0 & 0 & 0 & 0 \\
250 & 10,14 & 3,21 & 11,59 \\
500 & 20,28 & 6,43 & 23,18 \\
750 & 26,27 & 9,65 & 34,77 \\
\hline
\end{tabular}

Benih lamtoro digunakan adalah benih dalam bentuk biji degan ukuran seragam, bebas dari hama dan penyakit. Penanaman bibit lamtoro dilakukan pada setiap lubang tanam pada bedeng yang terlebih dahulu pada media tanam (polybag). Bibit lamtoro disemaikan selama 2 minggu sebelum dipindahkan pada lahan penelitian. Pembuatan bedeng atau petak percobaan dengan ukuran panjang $250 \mathrm{~cm} \times 150 \mathrm{~cm}$ dan pembuatan lubang tanam dengan jarak $50 \times 50$ $\mathrm{cm}$. Jarak antar blok $50 \mathrm{~cm}$ dan jarak antar petak $30 \mathrm{~cm}$. Penempatan perlakuan dilakukan dalam dua tahap. Tahap pertama adalah pengacakan antara blok atau kelompok perlakuan dan tahap kedua pengacakan terhadap perlakuan dalam tiap blok. Pemberian pupuk dilakukan seminggu sesudah pengolahan tanah sesuai dosis perlakuan. Dibiarkan (inkubasi) selama 2 minggu dengan tujuan agar mengurangi aktivitas mikroorganisme yang terdapat pada pupuk yang diberikan pada lahan. Penanaman dilakukan 2 minggu setelah aplikasi pupuk bokashi tepat pada lubang tanam yang telah disiapkan. Tanaman lamtoro disiram 2 kali dalam sehari yaitu pagi dan sore serta dilakukan penyulaman bila ada tanaman yang mati atau tidak tumbuh dan penyiangan atau pengendalian hama dan penyakit (bila terserang).

Pengambilan data dilakukan setiap minggu, berupa data tinggi tanaman yang diukur menggunakan penggaris berukuran 1 meter dari pangkal batang hingga ujung daun paling tinggi. Jumlah helai daun di ukur dengan cara menghitung semua helai daun yang tumbuh pada tanaman. Pada akhir masa penelitian dilakukan pemanenan untuk mendapatkan data berat segar dan kering daun serta akar.

Data yang diperoleh dalam penelitian ini dianalisis menggunakan analisa sidik ragam (Anova) berdasarkan Rancangan Acak Kelompok (RAK) dan dilanjutkan dengan uji jarak berganda Duncan untuk melihat perbedaan antar perlakuan (Steel \& Torrie, 1995).

\section{Hasil dan Pembahasan}

Penelitian diawali dengan survei lokasi dan persiapan lahan yakni melakukan pengukuran pada lahan penelitian dengan seluas $15 \times 7,5 \mathrm{~m}$, diikuti dengan pembersihan lahan dari rumput-rumput liar, pembajakan tanah, pengukuran panjang dan lebar bedeng, pengukuran jarak antar blok per bedeng, dilanjuti dengan pembuatan bedeng, penggemburan, pengukuran jarak tanam antara bedeng $30 \mathrm{~cm}$ dan tiap-tiap bedeng memiliki 15 unit lubang tanam. Tekstur tanah yang ditemui pada lahan penelitian ini yaitu tanah inceptisol. Sedangkan pupuk kandang diambil dari kandang peternak milik warga Kota Kefamenanu. Pupuk kandang yang dipakai yaitu pupuk kandang feses ayam murni diambil dua minggu sebelum penelitian berlangsung untuk melakukan pembuatan pupuk Bokashi, Sedangkan untuk bibit lamtoro diambil dari perkebunan warga di Desa Akomi, Kecamatan Miomaffo Tengah.

Penimbangan pada pupuk Bokashi sesuai dengan perlakuan masingmasing yakni terdiri dari R0, kontrol, R1, $250 \mathrm{~g}, \mathrm{R} 2,500 \mathrm{~g}$, dan R3, $750 \mathrm{~g}$ pupuk Bokashi yang siap digunakan pada penelitian dan ditempatkan pada setiap lubang tanam sesuai dengan perlakuan masing-masing dan dilanjutkan dengan persemaikan pada bibit lamtoro pada polybag yang sudah tersedia yang terbuat dari daun pisang sebanyak 240 polybag. Persemaian pada bibit lamtoro selama 1 minggu, kemudian dilakukan dengan penanaman pada lamtoro, setiap lubang tanaman yang akan ditanam/lubang tanam masing-masing terdapat satu pohon lamtoro, dan dilanjuti dengan pemeliharaan pada tanaman lamtoro dan dilakukan penyiraman pada lamtoro dua kali sehari yaitu pagi dan sore.

Tinggi tanaman merupakan salah satu parameter yang digunakan untuk mengukur pertumbuhan tanaman lamtoro. Hasil pengukuran terhadap tinggi tanaman selama penelitian dapat dilihat pada Tabel 2 .

Tabel 2. Nilai Rataan Tinggi Tanaman Lamtoro (cm)

\begin{tabular}{|c|c|c|c|c|c|c|}
\hline \multirow{2}{*}{ Pupuk Bokashi (g) } & \multicolumn{4}{|c|}{ Kelompok } & \multirow{2}{*}{ Total } & \multirow{2}{*}{ Rerata } \\
\hline & I & II & III & IV & & \\
\hline$\overline{\mathrm{R}_{0}(\text { Kontrol) }}$ & 22,74 & 26,05 & 33,14 & 16,39 & 98,31 & $24,58^{\mathrm{b}}$ \\
\hline $\mathrm{R}_{1}(250)$ & 27,36 & 34,84 & 31,00 & 30,34 & 123,54 & $30,88^{\mathrm{b}}$ \\
\hline $\mathrm{R}_{2}(500)$ & 34,08 & 36,74 & 45,59 & 38,73 & 155,15 & $38,79^{\mathrm{a}}$ \\
\hline $\mathrm{R}_{3}(750)$ & 34,68 & 47,91 & 44,78 & 46,67 & 174,04 & $43,51^{\mathrm{a}}$ \\
\hline Total & 118,85 & 145,54 & 154,51 & 132,14 & 551,04 & \\
\hline Rerata & 29,71 & 36,39 & 38,63 & 33,04 & & \\
\hline
\end{tabular}

Keterangan: Angka yang diikuti superscripct berbeda pada kolom yang sama menunjukkan berbeda nyata pada ( $\alpha$ ) $5 \%$ menurut uji Dunan.
Berdasarkan Tabel 2. memperlihatkan bahwa tanaman lamtoro yang diberi pupuk Bokashi padat dengan level yang berbeda mampu menghasilkan tinggi tanaman yang berbeda, di mana tinggi tanaman lamtoro terbaik dihasilkan pada perlakuan level pupuk Bokashi $750 \mathrm{~g}$ yang menghasilkan tinggi tanaman $43,51 \mathrm{~cm}$, diikuti perlakuan level $500 \mathrm{~g}$ sebesar $38,79 \mathrm{~cm}$; level $250 \mathrm{~g}$ sebesar $30,88 \mathrm{~cm}$ dan yang terendah adalah pada perlakuan Kontrol sebesar 24,58 cm.

Hasil analisis sidik ragam (anova) menunjukkan bahwa aplikasi pupuk Bokashi padat memberikan pengaruh sangat nyata $(\mathrm{p}<0,01)$ terhadap tinggi tanaman lamtoro. Hasil Uji jarak berganda duncan menunjukkan bahwa antara perlakuan level Bokashi $750 \mathrm{~g}$ dan $500 \mathrm{~g}$ menunjukkan tidak berbeda nyata $(p>0,05)$ terhadap tinggi tanaman lamtoro, tetapi berbeda sangat nyata $(p<0,01)$, dengan perlakuan level Bokashi $250 \mathrm{~g}$ dan Kontrol.

Peningkatan level Bokashi dalam penelitian ini telah menghasilkan karakteristik tinggi tanaman lamtoro yang berbeda, disebabkan semakin tingginya pemberian level Bokashi akan diikuti ketersediaan nutrien tanaman dalam bentuk N, P dan K yang semakin tinggi. Pemberian level Bokashi $750 \mathrm{~g}$ mampu menyediakan unsur $\mathrm{N}$ bagi tanaman sebesar $26,27 \mathrm{~g}$ dan lebih tinggi jika dibandingkan level Bokashi $500 \mathrm{~g}, 250 \mathrm{~g}$ maupun kontrol, sehingga tinggi tanaman yang dihasilkan lebih baik. Unsur $\mathrm{N}$ memegang peranan penting dalam menghasilkan tinggi tanaman. Menurut Novizan, (2007), bahwa senyawa nitrogen digunakan tanaman untuk membentuk asam amino yang akan diubah menjadi protein. Nitrogen juga dibutuhkan untuk senyawa penting seperti klorofil, asam nukleat dan enzim. Oleh karena itu nitrogen dibutuhkan dalam jumlah relatif besar pada setiap tahap pertumbuhan tanaman, khususnya pada tahap pertumbuhan vegetatif, perkembangan, batang, dan daun. Sedangkan menurut Winarso, (2005), menambahkan bahwa unsur $\mathrm{N}$ berguna dalam pertumbuhan vegetatif tanaman terutama daun, meningkatkan tinggi tanaman dan meningkatkan kemampuan tanaman menyerap unsur hara yang diaplikasikan

Jumlah helai daun merupakan salah satu parameter yang digunakan dalam menentukan produksi tanaman. Hasil perhitungan terhadap jumlah helai daun pada tanaman lamtoro selama penelitian dapat dilihat pada Tabel 3 .

\section{Tabel 3. Nilai Rataan Jumlah Helai Daun}

\begin{tabular}{lcccccc}
\hline \multirow{2}{*}{ Pupuk Bokashi (g) } & \multicolumn{2}{l}{ Kelompok } & & & \multirow{2}{*}{ Total } & \multirow{2}{*}{ Rerata } \\
\cline { 2 - 5 } & I & II & III & IV & & \\
\hline $\mathrm{R}_{0}($ Kontrol) & 30,09 & 36,32 & 44,93 & 23,34 & 134,68 & $33,67^{\mathrm{b}}$ \\
$\mathrm{R}_{1}(250)$ & 34,17 & 46,16 & 39,39 & 40,32 & 160,04 & $40,01^{\mathrm{b}}$ \\
$\mathrm{R}_{2}(500)$ & 42,87 & 48,14 & 63,57 & 55,59 & 210,18 & $52,55^{\mathrm{a}}$ \\
$\mathrm{R}_{3}(750)$ & 43,58 & 65,78 & 64,61 & 62,74 & 236,72 & $59,18^{\mathrm{a}}$ \\
\hline \multicolumn{1}{c}{ Total } & 150,72 & 196,41 & 212,50 & 181,99 & 741,62 & \\
\hline \multicolumn{1}{c}{ Rerata } & 37,68 & 49,10 & 53,13 & 45,50 & & \\
\hline
\end{tabular}

Keterangan: Angka yang diikuti superscripct berbeda pada kolom yang sama menunjukkan berbeda nyata pada $(\alpha) 5 \%$ menurut uji Duncan

Berdasarkan Tabel 3, di atas menunjukkan bahwa Jumlah helai daun tertinggi dihasilkan pada perlakuan level pupuk Bokashi $750 \mathrm{~g}$ yang menghasilkan jumlah helai daun sebanyak 59,18 helai diikuti perlakuan level Bokashi 500 g sebanyak 52,55 helai; level Bokashi 250 g sebanyak 40,01 helai dan yang terendah pada kontrol sebanyak 33,67 helai.

Hasil analisis sidik ragam (Anova) menunjukkan bahwa aplikasi pupuk Bokashi padat terhadap tanaman lamtoro berpengaruh sangat nyata $(\mathrm{p}<0,01)$ terhadap jumlah helai daun tanaman lamtoro yang dihasilkan. Hasil Uji jarak berganda duncan menunjukkan antara perlakuan level Bokashi 750 dan $500 \mathrm{~g}$ menghasilkan jumlah helai lamtoro yang tidak berbeda $(\mathrm{P}>0,05)$ namun berbeda dengan level $250 \mathrm{~g}$ dan kontrol. Tingginya jumlah helai daun pada perlakuan level Bokashi $750 \mathrm{~g}$ disebabkan karena semakin tingginya kandungan $\mathrm{N}$ yang disediakan bagi tanaman. Unsur $\mathrm{N}$ memegang peranan penting dalam proses fotosintesis. Hal ini didukung oleh hasil penelitian Agis (2016) yang menyatakan bahwa unsur $\mathrm{N}$ yang diserap oleh akar dan digunakan sebagai faktor utama penyusun klorofil dan meningkatkan berat segar akar. Semakin tercukupi unsur $\mathrm{N}$ pada tanaman maka pembentukan klorofil semakin tinggi, sehingga hasil fotosintesis semakin banyak. Tingginya hasil fotosintesis pada tanaman mengakibatkan jumlah daun semakin banyak.

Berat segar daun merupakan merupakan parameter penting menghitung produksi kumulatif yang dihasilkan. Hasil perhitungan terhadap berat segar daun tanaman lamtoro dapat dilihat pada Tabel 4.

Berdasarkan Tabel 4. menunjukkan Berat segar daun tertinggi dihasilkan pada perlakuan level Bokashi $750 \mathrm{~g}$ yaitu sebesar 21,79 g diikuti perlakuan level Bokashi $500 \mathrm{~g}$ sebesar 18,54 g; level Bokashi $250 \mathrm{~g}$ sebesar 10,09 g dan yang terendah pada perlakuan kontrol sebesar 6,65 g.

Hasil analisis sidik ragam (Anova) menunjukkan bahwa aplikasi pupuk Bokashi padat terhadap tanaman lamtoro berpengaruh sangat nyata $(p<0,01)$ terhadap jumlah berat segar daun tanaman lamtoro yang dihasilkan.

Hasil uji jarak berganda duncan menunjukkan antara perlakuan level Bokashi $750 \mathrm{~g}$ dan $500 \mathrm{~g}$ menghasilkan berat segar daun yang tidak berbeda nyata $(P>0,05)$ namun berbeda sangat nyata $(p<0,01)$ dengan level Bokashi $250 \mathrm{~g}$ dan kontrol. Unsur hara $\mathrm{N}$ memiliki peranan penting dalam fase vegetatif yaitu membantu dalam pembentukan fotosintesis yang selanjutnya digunakan untuk membentuk sel-sel baru, pemanjangan sel dan penebalan jaringan. Pembelahan sel dan pemanjangan serta pembentukan jaringan akan berjalan cepat sesuai dengan meningkatnya persediaan karbohidrat, sehingga pertumbuhan batang, 
baik tinggi tanaman, jumlah daun maupun luas daun akan berjalan dengan baik. Sehingga hal tersebut dapat meningkatkan berat segar daun tanaman, Fauzia, (2016).

Tabel 4. Nilai Rataan Berat Segar Daun Lamtoro (g)

\begin{tabular}{|c|c|c|c|c|c|c|}
\hline \multirow{2}{*}{ Pupuk Bokashi (g) } & \multicolumn{4}{|c|}{ Kelompok } & \multirow{2}{*}{ Total } & \multirow{2}{*}{ Rerata } \\
\hline & I & II & III & IV & & \\
\hline$\overline{\mathrm{R}_{0} \text { (Kontrol) }}$ & 5,02 & 6,84 & 11,58 & 3,15 & 26,59 & $6,65^{b}$ \\
\hline $\mathrm{R}_{1}(250)$ & 6,80 & 13,19 & 10,04 & 10,32 & 40,35 & $10,09^{b}$ \\
\hline $\mathrm{R}_{2}(500)$ & 12,32 & 16,94 & 26,12 & 18,78 & 74,16 & $18,54^{\mathrm{a}}$ \\
\hline$\underline{\mathrm{R}_{3}(750)}$ & 12,83 & 25,76 & 21,01 & 27,55 & 87,14 & $21,79^{\mathrm{a}}$ \\
\hline $\begin{array}{c}\text { Total } \\
\end{array}$ & 36,97 & 62,73 & 68,75 & 59,80 & 228,25 & \\
\hline Rerata & 9,24 & 15,68 & 17,19 & 14,95 & & \\
\hline
\end{tabular}

Keterangan: Angka yang diikuti superscripct berbeda pada kolom yang sama menunjukkan berbeda nyata pada $(\alpha) 5 \%$ menurut uji DMRT.

Berat kering daun pada tanaman lamtoro merupakan salah satu parameter yang digunakan untuk menghitung berat kering daun pada tanaman lamtoro. Hasil perhitungan terhadap berat kering daun pada tanaman lamtoro selama penelitian dapat dilihat pada Tabel 5 .

Tabel 5. Nilai Rataan Berat Kering Daun Lamtoro (g)

\begin{tabular}{lcccccc}
\hline \multirow{2}{*}{$\begin{array}{c}\text { Pupuk Bokashi } \\
\text { g }\end{array}$} & \multicolumn{9}{c}{ Kelompok } & \multirow{2}{*}{ Total } & \multirow{2}{*}{ Rerata } \\
\cline { 2 - 5 } & I & II & III & IV & & \\
\hline $\mathrm{R}_{0}($ Kontrol $)$ & 2,77 & 3,78 & 5,83 & 1,16 & 13,54 & $3,38^{\mathrm{c}}$ \\
$\mathrm{R}_{1}(250)$ & 3,01 & 6,68 & 3,99 & 3,67 & 17,35 & $4,34^{\mathrm{c}}$ \\
$\mathrm{R}_{2}(500)$ & 5,06 & 6,26 & 9,30 & 6,49 & 27,12 & $6,78^{\mathrm{b}}$ \\
$\mathrm{R}_{3}(750)$ & 5,56 & 11,56 & 8,41 & 8,29 & 33,82 & $8,45^{\mathrm{a}}$ \\
\hline \multicolumn{1}{c}{ Total } & 16,40 & 28,28 & 27,52 & 19,62 & 91,82 & \\
\hline \multicolumn{1}{c}{ Rerata } & 4,10 & 7,07 & 6,88 & 4,90 & &
\end{tabular}

Keterangan: Angka yang diikuti superscripct berbeda pada kolom yang sama menunjukkan berbeda nyata pada $(\alpha) 5 \%$ menurut uji DMRT.

Berdasarkan Tabel 5. di atas menunjukkan bahwa Berat kering daun lamtoro dapat berpengaruh terhadap Berat kering daun terus bertambah seiring dengan bertambahnya umur tanaman lamtoro yang diberi pupuk Bokashi padat dengan level yang berbeda, sehingga mampu mempengaruhi terhadap Berat kering daun pada tanaman lamtoro dengan data yang tertinggi terdapat pada perlakuan level Bokashi $750 \mathrm{~g}$, sebesar 8,45 g. Berat kering daun lamtoro dan data yang terendah terdapat pada perlakuan kontrol sebesar 3,38 g berat kering daun lamtoro.

Hasil analisis anova menunjukkan bahwa aplikasi pupuk Bokashi padat terhadap tanaman lamtoro berpengaruh sangat nyata $(\mathrm{p}<0,01)$ terhadap jumlah Berat kering daun tanaman lamtoro. Hasil Uji jarak berganda duncan menunjukkan bahwa pada perlakuan Bokashi $750 \mathrm{~g}$, berbeda sangat nyata $(\mathrm{p}<0,01)$ pada perlakuan Bokashi $500 \mathrm{~g}$, tetapi berbeda tidak nyata pada perlakuan Bokashi $250 \mathrm{~g}$ dan perlakuan kontrol ( $\mathrm{p}>0,05)$. Tanaman dengan kandungan $\mathrm{N}$ yang lebih tinggi memiliki daun yang lebih lebar dengan warna daun lebih hijau sehingga fotosintesis berjalan lebih baik. Hasil dari fotosintesis digunakan untuk perkembangan dan pertumbuhan tanaman, antara lain pertambahan ukuran panjang atau tinggi tanaman, pembentukan cabang dan daun baru, yang diekspresikan dalam bobot kering tanaman. Semakin tinggi fotosintesis yang dihasilkan diasumsikan semakin tinggi pula fotosintesis yang ditranslokasikan sehingga bobot kering tanaman akan meningkat (Sahari, 2007).

Berat segar akar pada tanaman lamtoro merupakan salah satu paramete yang digunakan untuk menghitung berat segar akar pada tanaman lamtoro. Hasil perhitungan terhadap berat segar akar pada tanaman lamtoro selama penelitian dapat dilihat pada Tabel 6.

Tabel 6. Nilai Rataan Berat Segar Akar Lamtoro (g)

\begin{tabular}{ccccccc}
\hline \multirow{2}{*}{\begin{tabular}{c} 
Pupuk Bokashi \\
\cline { 2 - 5 } \multicolumn{1}{c}{$\mathrm{g})$}
\end{tabular}} & $\mathrm{I}$ & $\mathrm{II}$ & $\mathrm{III}$ & $\mathrm{IV}$ & \multirow{2}{*}{ Total } & \multirow{2}{*}{ Rerata } \\
\hline $\mathrm{R}_{0}($ Kontrol $)$ & 3,70 & 4,24 & 7,66 & 2,47 & 18,06 & $4,52^{\mathrm{b}}$ \\
$\mathrm{R}_{1}(250)$ & 4,00 & 8,96 & 6,55 & 7,04 & 26,55 & $6,64^{\mathrm{b}}$ \\
$\mathrm{R}_{2}(500)$ & 7,29 & 10,69 & 13,01 & 10,71 & 41,71 & $10,43^{\mathrm{a}}$ \\
$\mathrm{R}_{3}(750)$ & 7,00 & 15,99 & 14,75 & 15,08 & 52,82 & $13,20^{\mathrm{a}}$ \\
\hline \multicolumn{1}{c}{ Total } & 21,98 & 39,88 & 41,97 & 35,31 & 139,14 & \\
\hline \multicolumn{1}{c}{ Rerata } & 5,50 & 9,97 & 10,49 & 8,83 & & \\
\hline
\end{tabular}

Keterangan: Angka yang diikuti superscripct berbeda pada kolom yang sama menunjukkan berbeda nyata pada $(\alpha) 5 \%$ menurut uji DMRT.

Berdasarkan Tabel 6. menunjukkan bahwa pemberian Bokashi sangat mempengaruhi terhadap berat segar akar lamtoro sampai pada tingkat sangat berbeda nyata $(\mathrm{p}<0,01)$, dengan rata-rata perlakuan Bokashi $750 \mathrm{~g}$, menghasilkan berat segar akar lamtoro paling tinggi yaitu 13,20 g dan data yang terendah terdapat pada perlakuan kontrol sebesar 4,52 g. Hasil analisis sidik ragam (Anova) menunjukkan bahwa aplikasi pupuk Bokashi padat terhadap tanaman lamtoro berpengaruh sangat nyata $(\mathrm{p}<0,01)$ terhadap jumlah berat segar akar tanaman lamtoro. Hasil Uji jarak berganda duncan menunjukkan bahwa pada perlakuan bokashi $750 \mathrm{~g}$, dan perlakuan Bokashi $500 \mathrm{~g}$, tidak berbeda sangat nyata $(p>0,05)$ tetapi pada perlakuan Bokashi $250 \mathrm{~g}$, dan perlakuan kontrol, berbeda sangat nyata $(\mathrm{p}<0,01)$.

Hal ini terkait dengan adanya kandungan unsur hara yang diserap oleh akar tanaman lamtoro, jika unsur hara tersebut tersedia maka penyerapan oleh akar cukup memadai dibanding bila tidak tersedia, sehingga sangat mempengaruhi terhadap jumlah berat segar akar pada tanaman lamtoro yang diberi pupuk Bokashi padat. Hal ini didukung oleh hasil penelitian Agis, (2016) yang menyatakan bahwa unsur $\mathrm{N}$ yang diserap oleh akar dan digunakan sebagai faktor utama penyusun klorofil dan meningkatkan berat segar akar.

Berat kering akar pada tanaman lamtoro merupakan salah satu parameter yang digunakan untuk menghitung berat kering akar pada tanaman lamtoro. Hasil perhitungan terhadap berat kering akar pada tanaman lamtoro selama penelitian dapat dilihat pada Tabel 7

Tabel 7. Nilai Rataan Berat Kering Akar Lamtoro (g)

\begin{tabular}{lcccccc}
\hline \multirow{2}{*}{$\begin{array}{c}\text { Pupuk Bokashi } \\
(\mathrm{g})\end{array}$} & $\mathrm{I}$ & $\mathrm{II}$ & $\mathrm{III}$ & $\mathrm{IV}$ & \multirow{2}{*}{ Total } & \multirow{2}{*}{ Rerata } \\
\cline { 2 - 5 } & 2,39 & 1,87 & 3,15 & 1,08 & 8,49 & $2,12^{\mathrm{b}}$ \\
$\mathrm{R}_{0}($ Kontrol $)$ & 1,99 & 3,97 & 2,92 & 3,05 & 11,93 & $2,98^{\mathrm{b}}$ \\
$\mathrm{R}_{1}(250)$ & 3,07 & 4,58 & 5,91 & 4,99 & 18,55 & $4,64^{\mathrm{a}}$ \\
$\mathrm{R}_{2}(500)$ & 3,44 & 7,07 & 6,22 & 6,22 & 22,96 & $5,74^{\mathrm{a}}$ \\
$\mathrm{R}_{3}(750)$ & 10,90 & 17,49 & 18,20 & 15,34 & 61,93 & \\
\hline \multicolumn{1}{c}{ Total } & 2,72 & 4,37 & 4,55 & 3,83 & & \\
\hline Rerata & & &
\end{tabular}

Keterangan: Angka yang diikuti superscripct berbeda pada kolom yang sama menunjukkan berbeda nyata pada $(\alpha) 5 \%$ menurut uji DMRT.

Berdasarkan Tabel 7. di atas menunjukkan bahwa pemberian Bokashi sangat mempengaruhi terhadap Berat kering akar lamtoro sampai pada tingkat sangat berbeda nyata $(\mathrm{p}<0,01)$, dengan rata-rata perlakuan Bokashi $750 \mathrm{~g}$, menghasilkan berat kering akar lamtoro paling besar yaitu 5,74 $\mathrm{g}$ dan yang paling terendah pada perlakuan kontrol dengan nilai rata-rata sebesar 2,12 g. Hasi analisis anova menunjukkan bahwa aplikasi pupuk Bokashi padat terhadap tanaman lamtoro berpengaruh sangat nyata $(\mathrm{p}<0,01)$ terhadap jumlah Berat kering akar tanaman lamtoro.

Hasil Uji jarak berganda duncan menunjukkan bahwa pada perlakuan Bokashi $750 \mathrm{~g}$, dan perlakuan Bokashi $500 \mathrm{~g}$, tidak berbeda sangat nyata $(\mathrm{p}>0,05)$ tetapi pada perlakuan bokashi $250 \mathrm{~g}$ dan perlakuan kontrol, berbeda sangat nyata $(\mathrm{p}<0,01)$. Hal ini terkait dengan adanya kandungan unsur hara yang diserap oleh akar tanaman lamtoro, sangat mempengaruhi terhadap berat kering akar pada tanaman lamtoro yang diberi pupuk Bokashi padat. Hal ini berkaitan erat dengan ketersediaan $\mathrm{N}$ dan $\mathrm{P}$ di dalam tanah, sehingga pemberian pupuk tidak mempengaruhi berat kering akar. Hal ini sejalan dengan pendapat Ningsih (2009) menyatakan bahwa pertumbuhan pada tanaman tidak bergantung pada pemupukan, karena dapat tercukupi dengan unsur yang tersedia dalam tanah.

\section{Simpulan}

Pemberian pupuk Bokashi padat berbahan dasar feses ayam sangat efektif dalam meningkatkan nilai kesuburan tanah sehingga dapat meningkatkan pertumbuhan dan produksi tanaman lamtoro. Pemberian pupuk Bokashi padat berbahan dasar feses ayam pada level $750 \mathrm{~g} /$ lubang tanam $\left(\mathrm{R}_{3}\right)$ memberikan hasi terbaik pada tinggi tanaman sebesar 43,51 cm/tanaman; Jumlah helai daun 59,18 helai/tanaman; Berat segar daun 21,79 g/tanaman; berat kering daun 8,45 g/tanaman; Berat segar akar 13,20 g/tanaman; Berat kering akar 5,74 g/tanaman Hasil ini lebih baik dibandingkan perlakuan level Bokashi $500 \mathrm{~g} / \mathrm{lubang}$ tanam $\left(\mathrm{R}_{2}\right), 250 \mathrm{~g} / \mathrm{lubang}$ tanam $\left(\mathrm{R}_{1}\right)$ maupun Kontrol $\left(\mathrm{R}_{0}\right)$.

\section{Pustaka}

Abou F.M.K, Sarmiento L, Santos R, Solorio F. 2011. Nutritional effects of diEtary inclusion of Leucaena leucocephala and Moringa oleifera leaf meal on Rhode Island Red hens' performance. Cuban J Agricultural Sci. 45:163-169

Agis Pratama. 2016. Pengaruh Berbagai Macam Medium Tanam dan Konsentrasi POC Urin Sapi Pada Pertumbuhan dan Hasil Caisim (Brassica junea L.) Dengan Sistem Wick Pot Hidroponik. Fakultas Pertanian. Universitas Muhammadiyah Yogyakarta. Skripsi. Yogyakarta

Cahyono B. 2008 Tomat: Usaha Tani dan Penanganan Pascapanen. Kanisius, Yogyakarta.

Devi M.V.N., V.N. Ariharan and P.N.Prasad. 2013. Nutritive Value and Potential Uses of Leucaena leucocephala as Biofuel. Research J of Pharmaceutical, Biological and Chemical Sci.Vol 4(1).: 515-521

Fauzia K. 2016. Percepatan Pengompasan Eceng Gondok (Eichornia crassipes S) Dengan Berbagai Campuran Bahan Hijauan Pada Aplikasi Tanaman Selada (Lactucabsativa L). Universitas Muhammadiyah Yogyakarta. Yogyakarta. Skripsi hal $38-39$

Handayani I. P. 2002. Laporan Penelitian Pendayagunaan Vegetasi Invasi Dalam Proses Agradasi Tanah Untuk Percepatan Restorasi Lahan Kritis Lembaga Penelitian Universitas Bengkulu, Bengkulu.

Haris \& Ahmad N, B. (2012). Factors for using derivatives: Evidence from Malaysian non-financial companies. Journal of finance and accounting. Vol 3. No 9. ISSN 2222-1697. 
Hindersah R. dan T. Simarmata. 2004. Artikel Ulas Balik. Potensi Rizobakteri Azotobacter dalam Meningkatkan Kesehatan Tanah. Jurnal Natur Indonesia. Vol.5(2). P: 127-133.

Ningsih D. P. 2009. Korelasi Kalium Tanah Ultisol dan Oksisol dengan Respons Tanaman Jagung. Fakultas Matematika dan Ilmu Pengetahuan Alam. Institut Pertanian Bogor. Bogor.

Novizan. 2007.Petunjuk Pemupukan yang Efektif. Jakarta: Agro Media Pustaka.

Pamungkas F. B, Endro Sutrisno, Sri Sumiyati. 2011. Pengaruh Variasi Waktu Fermentasi Terhadap Peningkatan Protein Pada Pakan Ternak Dari Campuran Isi Rumen Sapi Dan Limbah Kulit Kopi Dengan V Jamur Trichoderma Viride. Program Studi Teknik Lingkungan, Fakultas Teknik, Universitas Diponegoro. Semarang

Putri D. R., Agustono, Subekti S. 2012. Kandungan Bahan kering, serat kasar dan protein Kasar Pada daun Lamtoro (Leucaena glauca) Yang difermentasi dengan Probiotik Sebagai Bahan Pakan Ikan. Jurnal Ilmiah Perikanan dan kelautan Vol. 4 No. 2

Purwantari N.D. 2005. Forage Production of some lesser-known Leucaena spesies grown on acid soil. Indonesia J. Agric. Sci. 6: 46-51.

Purwanto, Imam., 2007. Mengenal Lebih Dekat Leguminoseae. Penerbit Kanisius. Yogyakarta.

Plantamor. 2012. Petai Cina dalam: http://plantamor.com/species/info/leucaena/leucocephala diunduh pada 1 Mei 2018

Sahari P. 2007. Pengaruh Jenis dan Pupuk Kandang terhadap Pertumbuhan dan Hasil Tanaman Kerokot Landa (Talinum triangulare Willd.). Jurnal Agriceca 7(1). http:/ejournal.utp.ac.id [1 Mei 2018].

Suhartati F.M. 2012. Proteksi protein daun lamtoro (Leucaena leucocephala) menggunakan tanin, saponin, minyak dan pengaruhnya terhadap ruminal undegradable dietary protein (RUDP) dan sintesis protein mikroba rumen. Anim. Production. 7 (1): 52-58

Sunardi. 2009. Mekanisme diuretik. http://www.Docstoc.com/docs/7804134/ diuretik-mekanisme. Html

Steel R.G.D. and J.H. Torrie. 1995. Prinsip dan Prosedur Statistika: Suatu Pendekatan Biometrik. Penerjemah: Sumantri, B. Gramedia Pustaka Utama, Jakarta.

Winarso S. 2005.Kesuburan Tanah: Dasar Kesehatan dan Kualitas Tanah. Gava media. Jogjakarta.269 hal.

Zayed J. Bakhiyi, B., Labreche, \& F. (2014). The photovoltaic industry on the path to a sustainable future-environmental and occupational health issues. Environment International, 73, 224-234. 